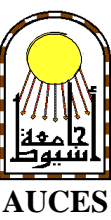

\title{
THE EFFECT OF WIND-CATCHERS EL-MALAQEF- ON THE INTERNAL NATURAL VENTILATION IN HOT CLIMATES WITH SPECIAL REFERENCE TO EGYPT: A STUDY ON SMALL PHYSICAL MODELS
}

\author{
Ahmed Abdel_Wahab Ahmed Rizk (Ph. D.) \\ Associate Professor, Department of Architecture, Faculty of Engineering, Tanta University \\ E-mail: rizk2003@yahoo.com \\ Mohamed Abd Elmawgoud Abd Elghaffar (Ph. D.) \\ Assistance Professor, Department of Architecture, Faculty of Engineering, Tanta University \\ E-mail: Mawgoud@hotmail.com
}

\begin{abstract}
:
The research problem has two parts. The first one expresses how to deliver air current (flow movement) due to wind pressure to cover all home parts. The other part expresses how to achieve the thermal comfort in the conditions of Egypt such as high temperatures and low wind speed of the prevailing cold wind. In this work, the effects of the geometrical characteristics of wind catchers on the internal natural ventilation is studied.

The aim of this study is to find a way to increase the wind speed from wind catcher all over the internal surrounding spaces. Small physical models is used to derivate the optimum geometrical characteristics of wind catchers that achieve the objective of this research than actual models. Also, the dimensions of the models of wind catchers are analyzed : The effect of the following items on air speed: The mainly second part discusses the controversial effects of the geometrical properties of wind catchers on air speed at wind catcher's air entries (inlets) and air exits (outlets). These effects are:

1- Different orientations of the entry openings.

2-Different inlet/outlet area ratio.

3-Different numbers and locations of air exits.

4-Cross-areas of the air tunnel and its different forms.

5 -The roof angles of wind-catcher.

The conclusions of the paper can summarize the conditions under which air speed - at both inlet and outlet openings - increases as follows: When the long axis of the air-entry opening is perpendicularly placed to the wind direction. When the inlet opening area is smaller than the outlet opening area. When the outlet opening is faced inlet opening. When the air tunnel cross-area gets smaller or turns into a circular shape. And when the wind catcher roof angle is between $30^{\circ}$ and $55^{\circ}$.
\end{abstract}




\section{EXPERIMENTAL DESIGN:}

Experiments are carried out using small physical models $(15 \times 15 \times 50) \mathrm{cm}, 11 \times 11 \mathrm{~cm}$ surface area of the inlet opening and finally $11 \times 11 \mathrm{~cm}$ area of the outlet opening.

By studying the effect of the geometrical characteristics of wind catcher on air speed at both entry opening and exit openings, it is easy to derive the optimum geometrical characteristics of actual wind catchers that depends on the calculation air speed at both entry. And exit openings.

\section{RESULTS AND DISCUSSION:}

The effect of the geometrical characteristics of wind catcher on air speed of both entry openings and exit openings.

\section{1-Entry Opening's Orientations (Inlet Orientations):}

It is found that the effects of different orientations of air entry openings according to wind direction, air speed at outlet openings are as follows:

- It equals to $90 \%$ of the speed of the external wind, when the long axis of the wind catcher's entry opening is perpendicular to the wind direction.

- It reaches to $50 \%$ of the speed of the external wind, when the long axis of the wind catcher's entry opening is at an angle between $10^{\circ}$ to $80^{\circ}$ to the wind direction.

- It is nil, when the long axis of the wind catcher's entry opening is parallel to wind direction as given in table (1). It is concluded that air speed at outlet opening reaches its maximum value when the inlet opening is perpendicularly placed to the wind direction. It also vanishes when the surface of inlet opening is placed parallel to wind direction as shown in figure (1).

\section{2-Locations of Outlet Openings to Inlet Openings:}

Air speed at outlet openings varies according to the location of the outlet with respect to the inlet openings. When the outlet opening faces the inlet opening, air speed increases to a double value of that when the outlet opening located in the same side of the inlet opening as given in table (2), and shown in figure (2).

\section{3-Location of Outlet openings to Ground Level :}

It is found that the air speed at outlet opening increases when it is near to ground level as given in table (3), and as shown figure (3).

\section{4-The Number of the Outlet Openings:}

The number of outlet openings-the surface area of each one of them equals $11 \times 11 \mathrm{~cm}-$ affects air speed at outlet opening. The smaller of the number of outlet openings, the increase of air speed as given in table (4), and as shown in figure (4).

\section{5-The area of the outlet openings:}

It was observed that the percentage of the wind speed increases by the increase of the area of outlet opening as given in table (5) and shown in figure (5).

6-The cross sectional-area of the air tunnel :

It was observed that air speed at outlet openings increases when the cross area of air tunnel decreases as given in table (6), and as shown in figure (6).

\section{7-The Angle of Wind Catcher's Roof:}

Studying the different angles of wind catchers' roof, several values of air speed at exit opening are recorded: 
- The maximum value reaches $94 \%$ of the external wind speed when the angle of wind catcher's roof equals to $30^{\circ}$.

- It Reaches $85 \%$ of the external wind speed when the angle of wind catcher's roof equals $0^{\circ}$ (horizontal position).

- It Reaches $57 \%$ of the external wind speed when the angle of wind catcher's roof equals to $45^{\circ}$.
- It reaches $30 \%$ of the external wind speed when the angle of wind catcher's roof equals to $60^{\circ}$.

It was found that the effect of the angle of wind catcher's roof depends on two factors, the location of the outlet opening to the ground level, and the area of the outlet opening.

Table (1): Air speed and orientation of inlet opening

\begin{tabular}{|c|c|c|c|c|c|c|c|c|c|c|}
\hline \multirow{2}{*}{$\begin{array}{c}\text { Angle of } \\
\text { orientation }\end{array}$} & \multicolumn{10}{|c|}{ The angle of inlet opening surface to wind direction } \\
\hline & $90^{\circ}$ & $\mathbf{8 0}^{\circ}$ & $\mathbf{7 0}^{\circ}$ & $60^{\circ}$ & $\mathbf{5 0}^{\circ}$ & $\mathbf{4 0}^{\circ}$ & $30^{\circ}$ & $20^{\circ}$ & $10^{\circ}$ & $\mathbf{0}^{\circ}$ \\
\hline $\begin{array}{c}\text { Air speed at } \\
\text { outlet opening }\end{array}$ & $90 \%$ & $75 \%$ & $65 \%$ & $60 \%$ & $60 \%$ & $55 \%$ & $35 \%$ & $15 \%$ & $7.5 \%$ & $0 \%$ \\
\hline
\end{tabular}

Table (2): Location of inlet/outlet openings and air speed

\begin{tabular}{||c|c|c|}
\hline Location of outlet openings & $\begin{array}{c}\text { The outlet openings faced inlet } \\
\text { opening }\end{array}$ & $\begin{array}{c}\text { The outlet openings in the same side } \\
\text { of inlet opening }\end{array}$ \\
\hline $\begin{array}{c}\text { Average air speed at outlet } \\
\text { openings }\end{array}$ & $3 \mathrm{~m} / \mathrm{s}$ & $1.7 \mathrm{~m} / \mathrm{s}$ \\
\hline
\end{tabular}

Table (3): Location of outlet opening to the ground level

\begin{tabular}{|c|c|c|c|c|c|c|c|}
\hline \multirow{2}{*}{\multicolumn{2}{|c|}{ Location to ground level }} & \multicolumn{6}{|c|}{ Air speed at outlet openings meter/second } \\
\hline & & \multirow{2}{*}{$\begin{array}{c}\begin{array}{l}\text { Read } \\
(\mathrm{m} / \mathrm{s})\end{array} \\
2.6\end{array}$} & \multirow{2}{*}{$\begin{array}{c}\begin{array}{l}\text { No } 1 \\
(\%)\end{array} \\
95\end{array}$} & \multirow{2}{*}{$\begin{array}{c}\begin{array}{l}\text { Read } \\
(\mathrm{m} / \mathrm{s})\end{array} \\
2.7\end{array}$} & \multirow{2}{*}{$\begin{array}{l}\text { No } 2 \\
(\%) \\
100\end{array}$} & \multirow{2}{*}{$\begin{array}{c}\begin{array}{r}\text { Read } \\
(\mathrm{m} / \mathrm{s})\end{array} \\
2.2\end{array}$} & \multirow{2}{*}{$\begin{array}{l}\text { No } 3 \\
(\%) \\
\end{array}$} \\
\hline \multirow{4}{*}{$\begin{array}{c}\text { The outlet opening } \\
\text { that face inlet } \\
\text { opening }\end{array}$} & Upper part & & & & & & \\
\hline & Medium & 2.2 & 80 & 2.7 & 100 & 2.2 & 7.5 \\
\hline & Lower & 2.0 & 75 & 2.6 & 75 & 2 & 75 \\
\hline & Note: & \multicolumn{2}{|c|}{$\begin{array}{l}\text { Opened upper } \\
\text { outlet opening }\end{array}$} & \multicolumn{2}{|c|}{$\begin{array}{l}\text { Opened medium } \\
\text { outlet opening }\end{array}$} & \multicolumn{2}{|c|}{$\begin{array}{l}\text { Opened lower } \\
\text { outlet opening }\end{array}$} \\
\hline
\end{tabular}

Table (4): Number of outlet openings and air speed

\begin{tabular}{||c|c|c|c||}
\hline \hline The number of outlet openings & 6 openings & 3 openings & 2 openings \\
\hline Average air speed at outlet & $1.7 \mathrm{~m} / \mathrm{s}$ & $1.96 \mathrm{~m} / \mathrm{s}$ & $2.55 \mathrm{~m} / \mathrm{s}$ \\
openings & $65 \%$ & $75 \%$ & $100 \%$ \\
\hline
\end{tabular}

Table (5): Air speed and area of outlet openings

\begin{tabular}{||c|c|c|c|c|c|c||}
\hline Area of outlet opening $\left(\mathrm{cm}^{2}\right)$ & $14 \times 10$ & $13 \times 10$ & $12 \times 10$ & $11 \times 10$ & $10 \times 10$ & $9 \times 10$ \\
\hline Air speed at outlet opening $(\mathrm{m} / \mathrm{s})$ & 2.35 & 2 & 1.65 & 1.3 & 1 & 0.75 \\
\hline
\end{tabular}

Table (6): Air speed at outlet opening/and cross-area of air tunnel

\begin{tabular}{|c|c|c|c|c|c|c|}
\hline Cross areas of air tunnel $\left(\mathrm{cm}^{2}\right)$ & 121 & 144 & 155 & 169 & 196 & 225 \\
\hline Air speed at outlet opening/ external wind speed (\%) & 90 & 76 & 73 & 66 & 65 & 60 \\
\hline
\end{tabular}

Table (7): Air speed and the angle of wind catcher's roof

\begin{tabular}{||c|c|c|c|c|}
\hline \multirow{2}{*}{ Location } & \multicolumn{3}{|c|}{ The angle of wind catcher's roof } \\
\cline { 2 - 5 } & $\mathbf{0}^{\circ}$ (horizontal) & $30^{\circ}$ & $4^{\circ}$ & $\mathbf{6 0}^{\circ}$ \\
\hline The average air speed at outlet opening & $\mathbf{8 5 \%}$ & $\mathbf{9 4 \%}$ & $\mathbf{5 7 \%}$ & $\mathbf{3 0 \%}$ \\
\hline
\end{tabular}




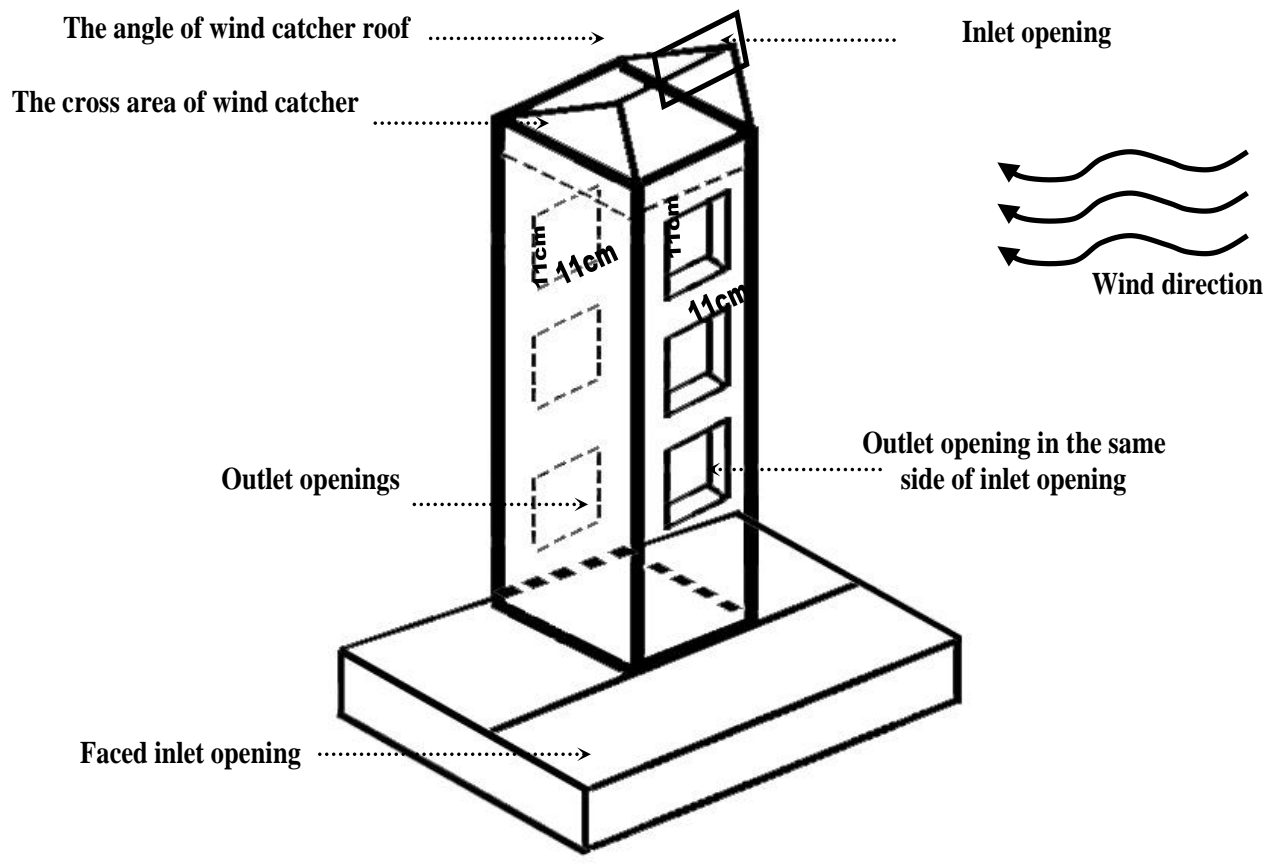

Fig. (0): The physical small model of wind catcher

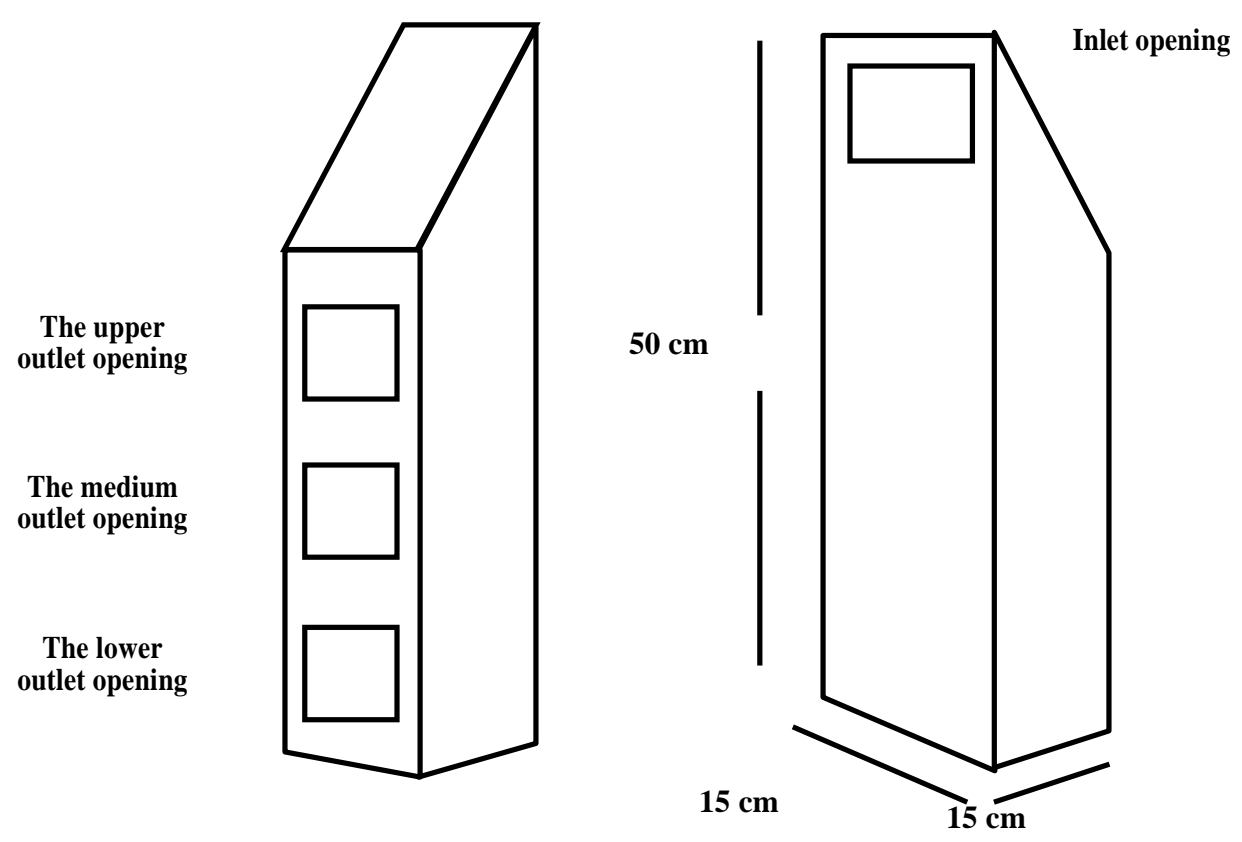




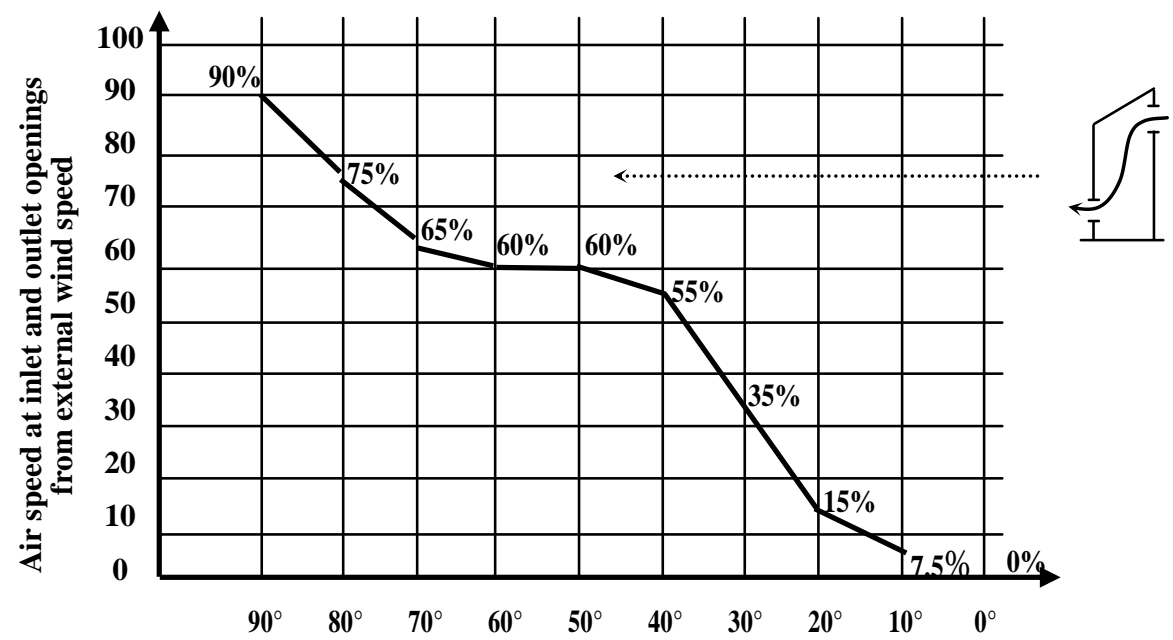

Fig. (1): The effect of the verity entry opening's orientation according to wind direction

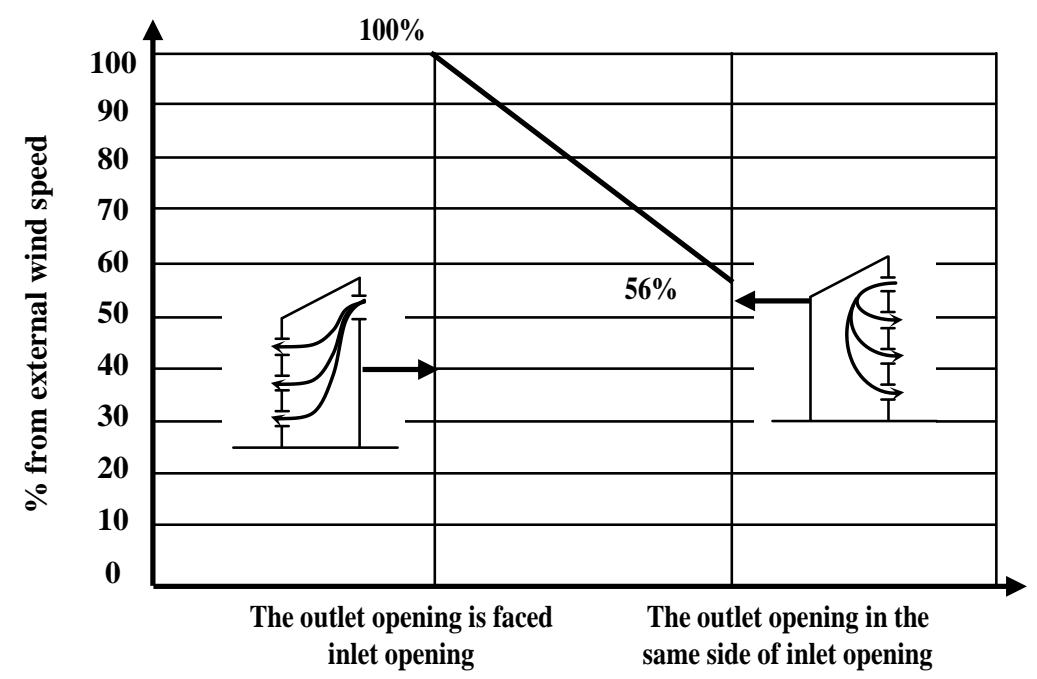

Fig. (2): The effect of location of outlet openings according to face inlet opening 


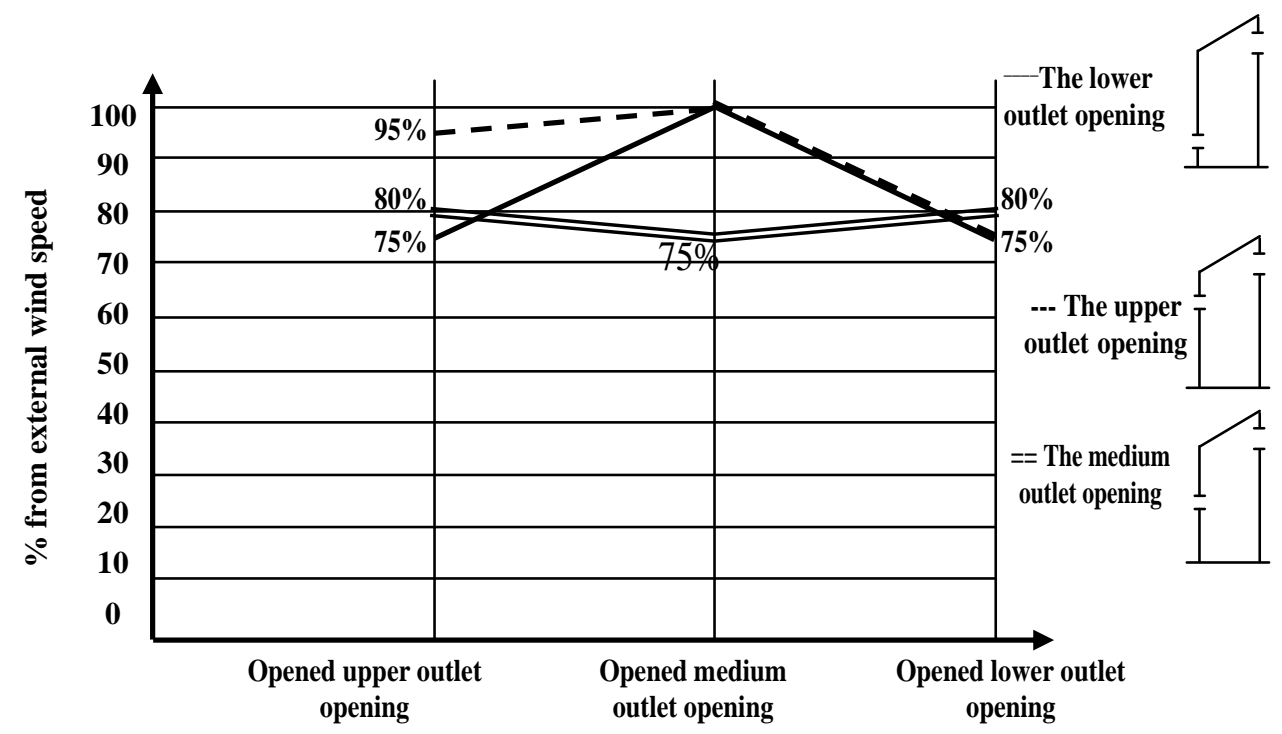

Fig. (3): The effect of location of outlet openings according to ground level

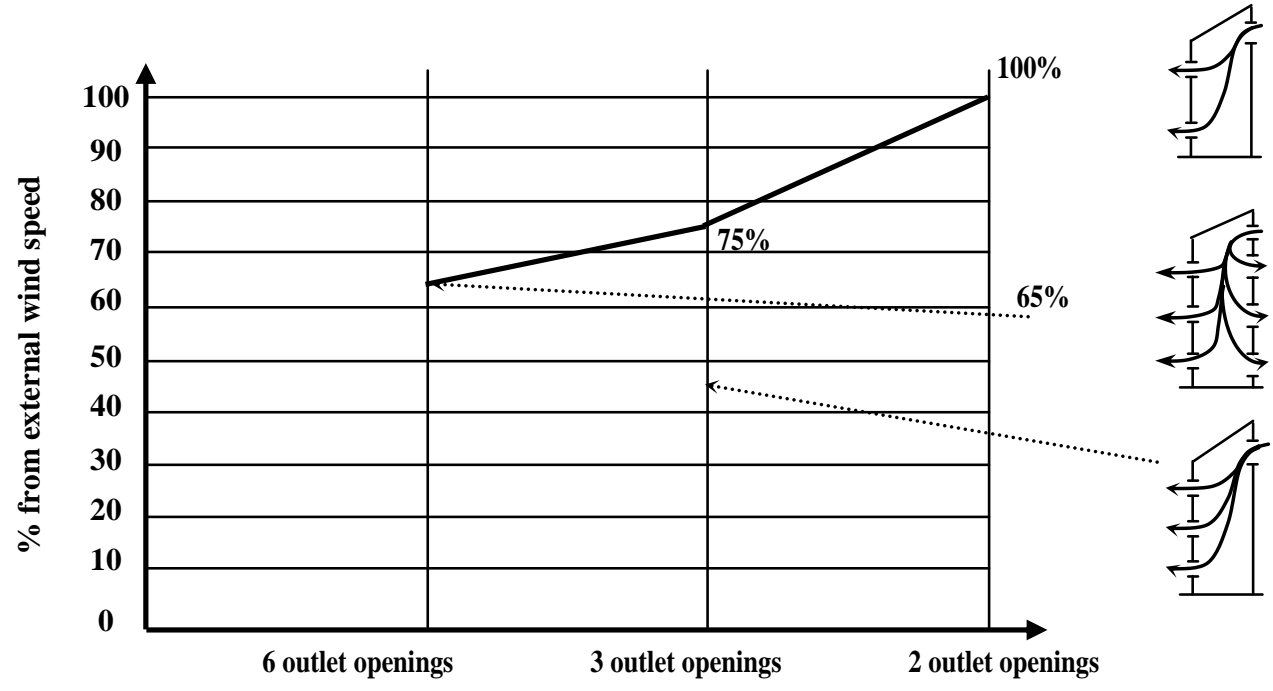

Fig. (4): The effect of the number of the outlet openings 


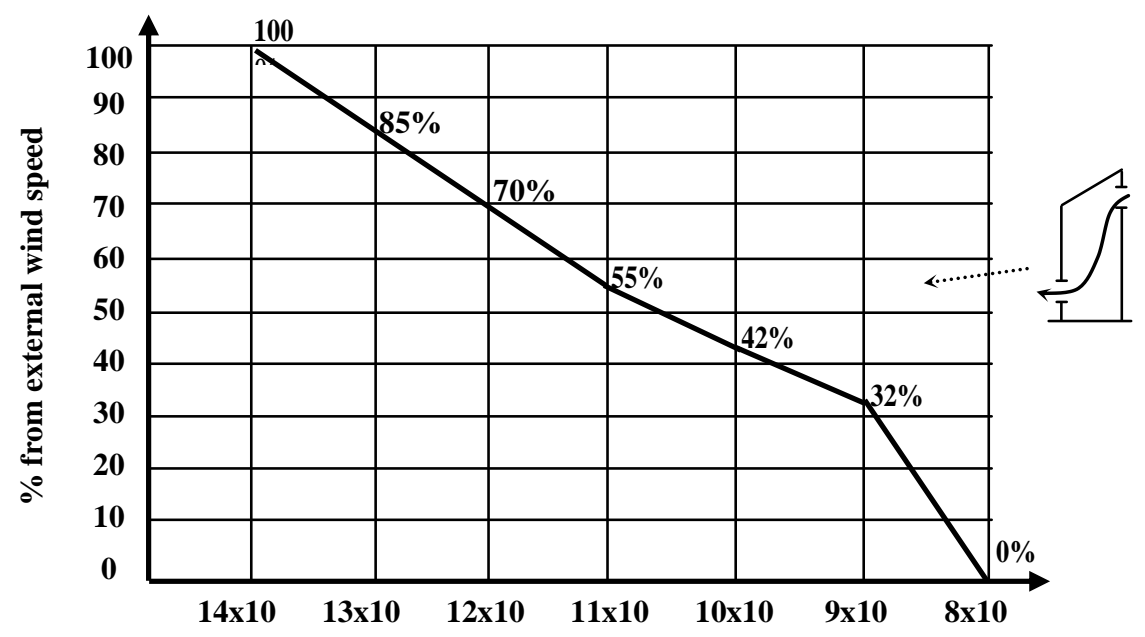

Fig. (5): The effect of area of outlet openings $\left(\mathrm{cm}^{2}\right)$

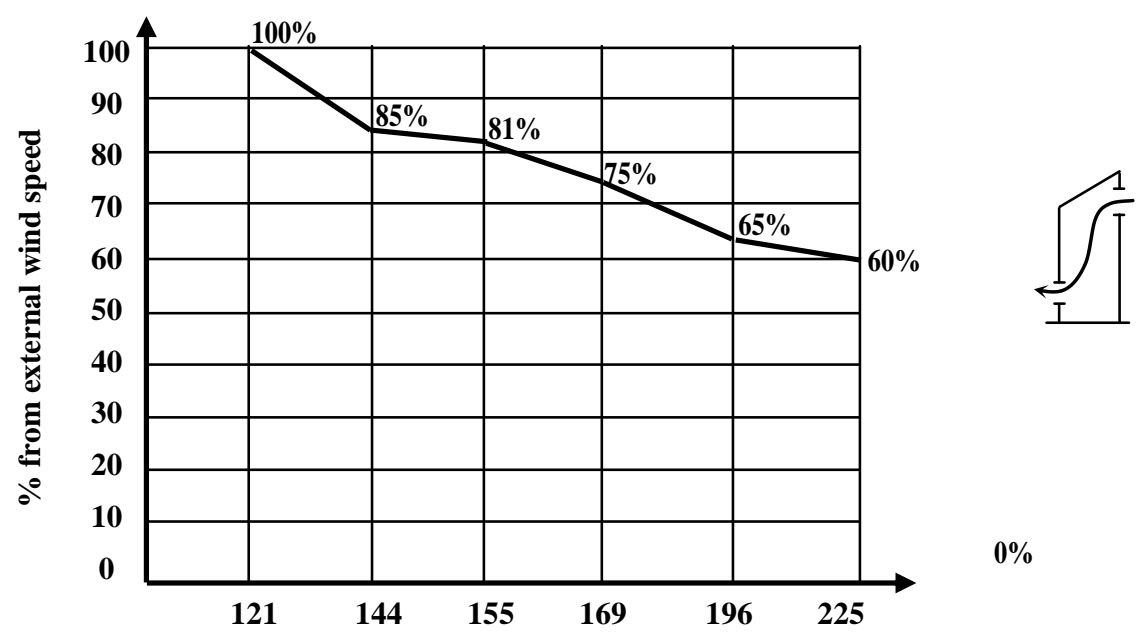

Fig. (6): The effect of area of cross area of air tunnel $\left(\mathrm{cm}^{2}\right)$ 


\section{A-The location of the outlet opening:}

Air speed Increases at outlet openings when the outlet is near to the ground level, when the angle of wind catcher's roof equals to $30^{\circ}$, air speed at the outlet openings nearly equals the external wind speed. While when the outlet opening is located in the upper part, air speed at the outlet opening decreases to be just $80 \%$ of the external wind speed, as given in table (7-a), and as shown in figure (7-a).

\section{B-The area of the outlet opening:}

Air speed at the outlet opening decreases as the area of outlet decreases, at the half area of outlet opening air speed records only 50 to $60 \%$ of external wind speed, as given in table (7-b), and as shown in figure (7-b).

The table (7-c) was summarized the three factors; the angle of wind catcher roof, the location of outlet openings and the area of outlet openings.

Table (7-a): The effect of the location of outlet opening according to ground level with the angle of wind catcher roof in the case of complete outlet openings

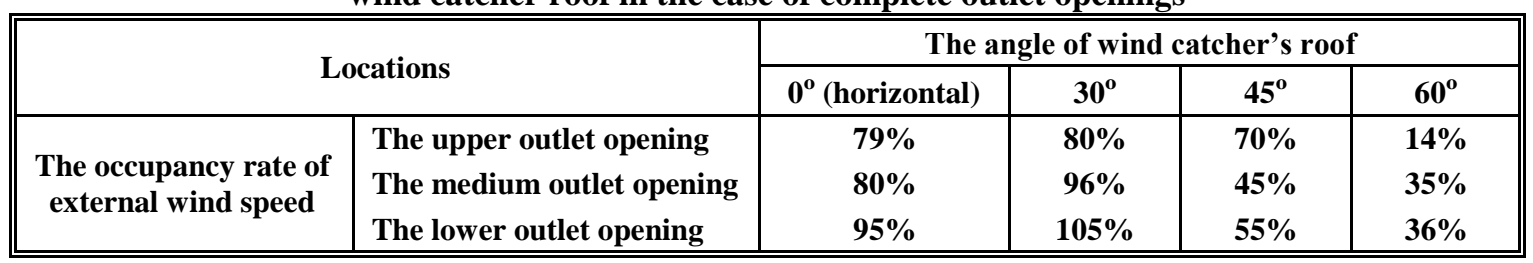

Table (7-b): Average air speed, area of outlet, and the angle of wind catcher's roof

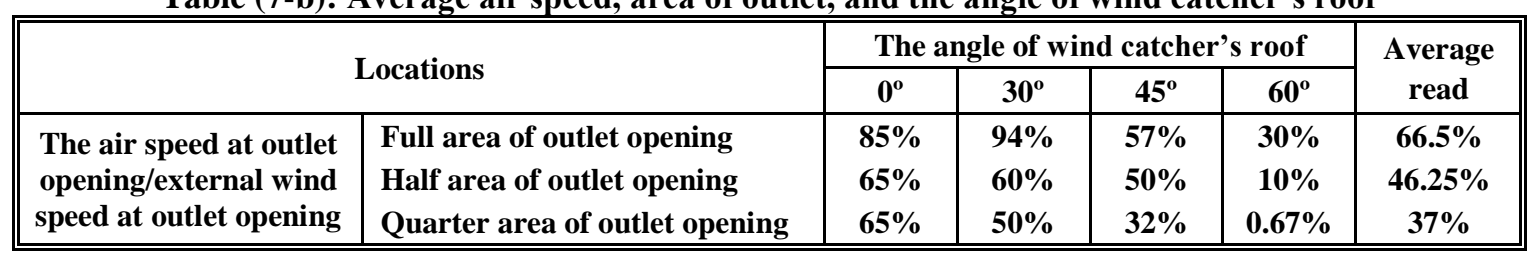

Table (7-c): Air speed, outlet location, area of outlet, and the angle of wind catcher's roof

\begin{tabular}{|c|c|c|c|c|c|}
\hline \multirow{2}{*}{\multicolumn{2}{|c|}{ Locations }} & \multicolumn{4}{|c|}{ The angle of wind catcher's roof } \\
\hline & & \multirow{3}{*}{$\begin{array}{c}0^{\circ} \\
79 \% \\
80 \% \\
95 \%\end{array}$} & \multirow{3}{*}{$\begin{array}{c}30^{\circ} \\
80 \% \\
96 \% \\
105 \%\end{array}$} & \multirow{3}{*}{$\begin{array}{c}45^{\circ} \\
70 \% \\
45 \% \\
55 \%\end{array}$} & \multirow{3}{*}{$\begin{array}{c}60^{\circ} \\
14 \% \\
35 \% \\
36 \%\end{array}$} \\
\hline & The upper outlet opening & & & & \\
\hline oper & The lower outlet opening & & & & \\
\hline & Average & $85 \%$ & $94 \%$ & $57 \%$ & $28 \%$ \\
\hline \multirow{3}{*}{$\begin{array}{l}\text { The air speed at outlet } \\
\text { opening/external wind speed } \\
\text { (Half area of outlet opening) }\end{array}$} & The medium outlet opening & $75 \%$ & $60 \%$ & $43 \%$ & $20 \%$ \\
\hline & The lower outlet opening & $50 \%$ & $47 \%$ & $44 \%$ & $2.5 \%$ \\
\hline & Average & $65 \%$ & $60 \%$ & $50 \%$ & $10 \%$ \\
\hline $\begin{array}{c}\text { The air speed at outlet } \\
\text { opening/external wind speed } \\
\text { (Quarter area of outlet opening) }\end{array}$ & The upper outlet opening & $71 \%$ & $48 \%$ & $45 \%$ & $0.72 \%$ \\
\hline
\end{tabular}




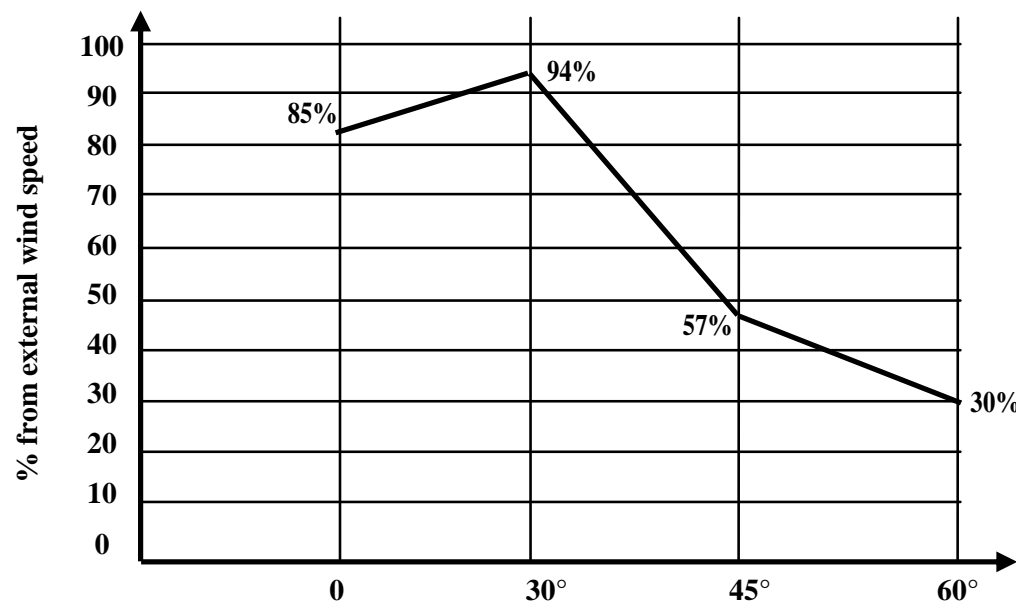

Fig. (7): The effect of the angle of wind catcher roof

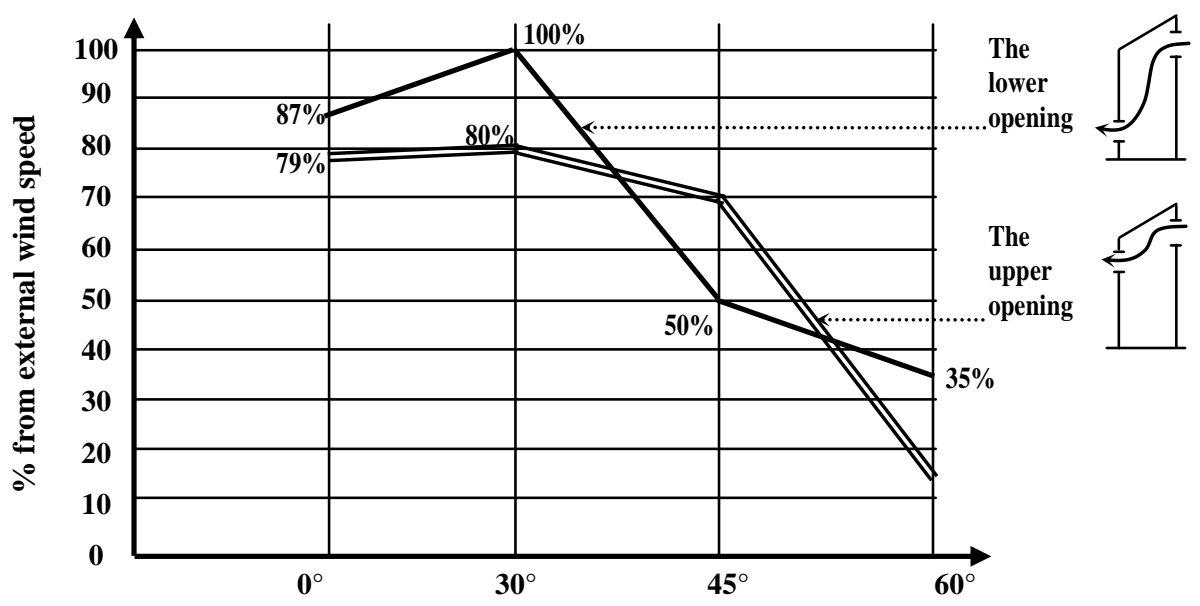

Fig. (7-a): The effect of the angle of wind catcher roof on the complete outlet openings with location of outlet openings 


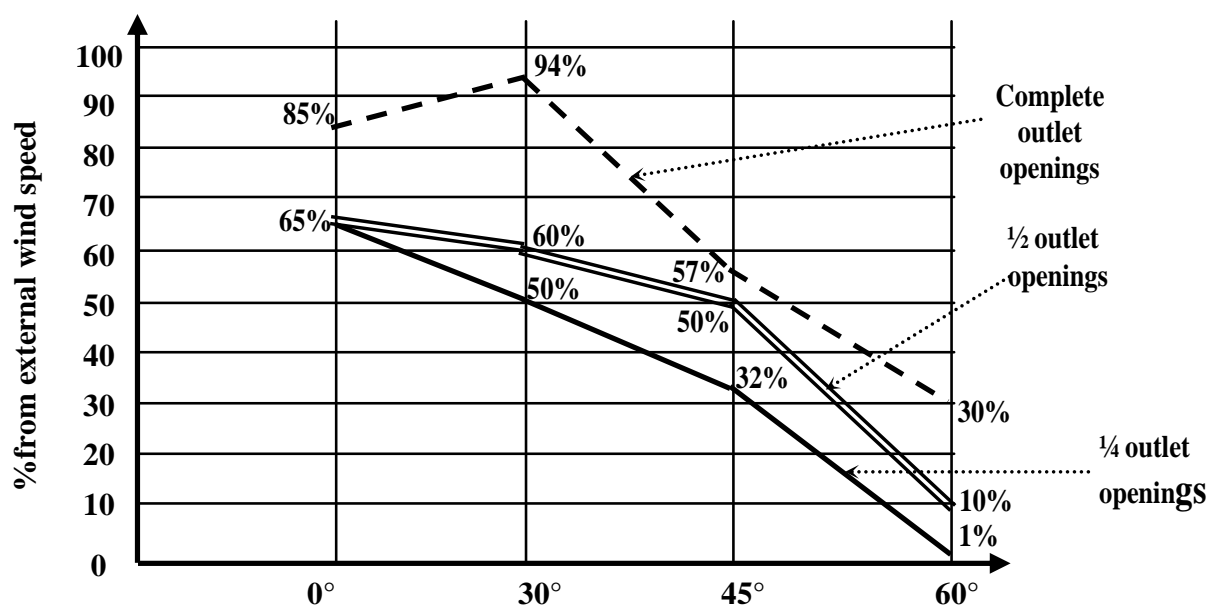

Fig. (7-b): The effect of area of outlet openings with the angle of wind catcher roof

\section{CONCLUSIONS:}

From the above study, it can be concluded that the effects of the geometrical characteristics of wind catchers on the air speed at outlet opening, takes the following forms :

- When the long axial of wind catcher's inlet opening is perpendicular to wind direction.

- When the outlet opening faces the inlet opening.

- When having fewer number of the outlet openings.

- When the surface area the outlet opening increases.

- When the cross area of air tunnel decreases.

- When the angle of wind catcher's roof equals to $30^{\circ}$.

- When the outlet opening is located near of ground level.

\section{RECOMMENDATIONS:}

Aerodynamic studies should be encouraged to reach the thermal comfort in the indoor environment to reduce the loads on energy used in air conditioning and artificial ventilations.
Future studies should be carried out to investigate the performance of real models similar to the models studied in this paper.

\section{REFERENCES:}

1-Bahadori, M., Viability of Wind Towers in achieving Summer Comfort in the Hot Arid Regions, Brighton, Elservier Science Ltd, 2000.

2-Elmualim, A., Dynamic Modeling of a Windcatcher/Tower for Natural Ventilation, Building Service Engineering, Vol. 27, No. 3, UK, 2006.

3-Elmualim, A., Modeling of Windcatcher for Natural Ventilation, National Renewable Energy Laboratory, Denver, Colorado. USA. 2004.

4-Fathy, H., Natural Energy and Vernacular Architecture, Chicago Press, 1986.

5-Givoni, Man, Climate and Architecture, Elsevier Publishing, 1969.

6-Harris, D., Web, R., Wind Towers' Old Technology to solve a New Problem', 17 th. AIVC, Gothernburg, Sweden,1996.

7-Koenigsberger, Ingersoll, Mayhew, Szokolay, Manual of Tropical Housing and Building, Longman Group Limited, London, 1974. 
Ass. Univ. Bull. Environ. Res. Vol. 10 No. 1, March 2007

$-11-$ 
تأثير الملاقف وخصائصها الهندسية على التهوية الطبيعية الداخلية

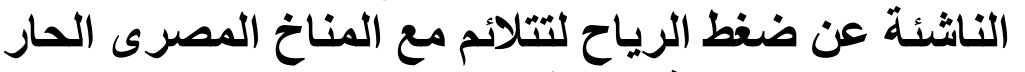

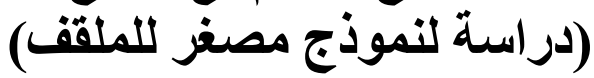

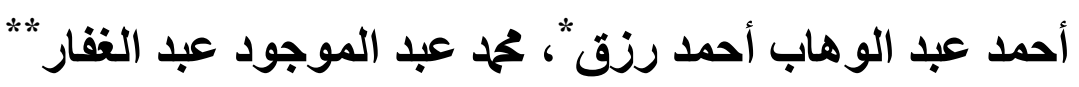

*الأستاذ المساعد، ** مدرس بقسم الهندسة المعمارية - كلية الهندسة - جامعة طنطا

يهاف البحث نحو زيـادة سرعة الهواء عند فتحات مخـارج الهواء للملقف عن طريق استغلال الخصائص

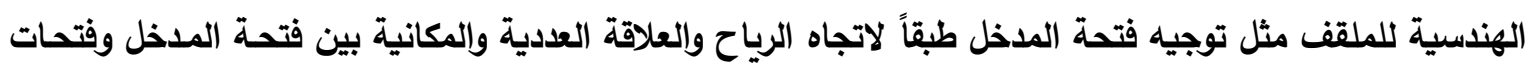

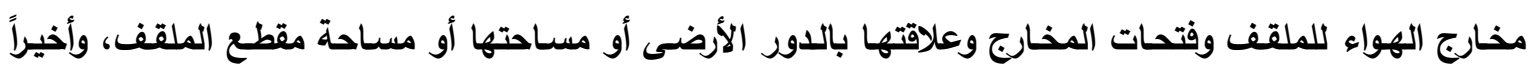
زاوية ميل الملقف ويتم بواسطة تجارب على نموذج مصغر للملقف وجهاز قياس سرعة الهواء ومروحة هوائية. وتوصلنا إلى أن سرعة الهواء تزداد عند فتحات مخارج الهواء فى الحالات التالية: • عند توجيه فتحة المدخل بمحورها الطويل بصورة عمودية على اتجاه الرياح. • عندما تكون فتحات مداخل الهواء أصغر من فتحات مخارج الهواء للملقف.

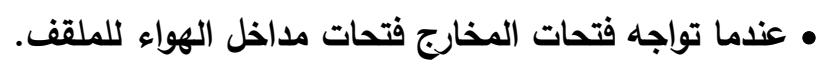
• عندما تقل مساحة فتحة المخرج. • عندما تقل المساحة الداخلية للملقف.

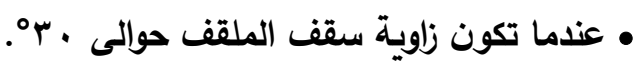

